\title{
Characterization of resistance of winter wheat varieties to Fusarium head blight
}

\author{
T.Yu. Gagkaeva ${ }^{1} \otimes$, A.S. Orina ${ }^{1}$, O.P. Gavrilova ${ }^{1}$, I.B. Ablova ${ }^{2}$, L.A. Bespalova ${ }^{2}$ \\ ${ }^{1}$ All-Russian Institute of Plant Protection, St. Petersburg, Pushkin, Russia \\ ${ }^{2}$ National Center of Grain named after P.P. Lukyanenko, Krasnodar, Russia
}

In this study, naturally and artificially inoculated winter wheat varieties were studied with respect to their productivity and resistance to Fusarium head blight (FHB). We used the following set of disease assessment parameters: the percentage of visually and latent Fusarium-damaged grains (FDG); the DNA content of Fusarium fungi; the productivity of inoculated plants compared with non-inoculated plants; and the amount of mycotoxins in the grain. In case of naturally infected grains, the average FDG was found to be about $6.1 \%$ (range of $0-15 \%$ ). The amount of DNA of Fusarium graminearum was found to be in the range of $(1.1-42.7) \times 10^{-5} \mathrm{ng} / \mathrm{ng}$ wheat DNA. The mycotoxin deoxynivalenol (DON) was detected in 15 samples of grain from plants that were grown under natural infection. The maximum DON amount was found to be $420 \mu \mathrm{g} / \mathrm{kg}$. Fumonisin $\mathrm{B}_{1}\left(\mathrm{FB}_{1}\right)$ was not be detected in naturally infected grain. In case of artificially inoculated plants, the average FDG was found to be $25.8 \%$ (2-54 \%). The amount of F. graminearum DNA was found to be significantly higher (4.2449.8) $\times 10^{-3} \mathrm{ng} / \mathrm{ng}$ than it was detected in grain of non-inoculated plants. The wheat varieties inoculated with F. graminearum contained DON in high amounts from 20255 to $79245 \mu \mathrm{g} / \mathrm{kg}$. Furthermore, a significant amount of $\mathrm{FB}_{1}$ was detected in all wheat varieties in the range of $980-20326 \mu \mathrm{g} / \mathrm{kg}$. Among the analysed wheat varieties, Adel was characterized to be the most resistant to fungal infection as well as to the contamination by mycotoxins. Antonina, Lebed and Pamyat varieties were classified more relatively resistant than that of other varieties, and Utrish variety was found to be the most susceptible to FHB. The similar resistance of wheat varieties against $F$. graminearum and $F$. verticillioides infection was recorded, and the interactions between the fungi during the colonization of grain were shown.

Key words: wheat; varieties; resistance; fungi; Fusarium; DNA; mycotoxins; artificial inoculation; quantitative PCR.
HOW TO CITE THIS ARTICLE:

Gagkaeva T.Yu., Orina A.S., Gavrilova O.P., Ablova I.B., Bespalova L.A. Characterization of resistance of winter wheat varieties to Fusarium head blight. Vavilovskii Zhurnal Genetiki i Selektsii = Vavilov Journal of Genetics and Breeding. 2018;22(6):685-692. DOI 10.18699/VJ18.411

\section{Характеристика сортов озимой пшеницы по устойчивости к фузариозу зерна}

Т.Ю. Гагкаева ${ }^{1} \otimes$, А.С. Орина ${ }^{1}$, О.П. Гавримова ${ }^{1}$,

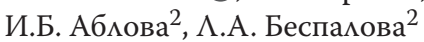
1 Всероссийский научно-исследовательский институт защиты
растений, Санкт-Петербург, Пушкин, Россия
2 Национальный центр зерна им. П.П. Лукьяненко, Краснодар,
Россия

По продуктивности и устойчивости к фузариозу на естественном фоне инфекции и на фоне искусственной инокуляции грибом Fusarium graminearum исследовали 17 сортов озимой пшеницы селекции Национального центра зерна им. П.П. Лукьяненко. Оценку сортов проводили на основании показателей, описывающих различные типы устойчивости: процентное содержание фузариозных зерен, выявленных по внешним признакам и в результате микологического анализа, а также содержание ДНК грибов Fusarium; показатели продуктивности инокулированных растений в сравнении с неинокулированными; количество микотоксинов в зерне. На естественном фоне, согласно результатам микологического анализа, зараженность зерна грибами рода Fusarium была в среднем 6.1 \% (0-15 \%), количество ДНК F. graminearum варьировало в диапазоне (1.1-42.7) × 10 пшеницы, дезоксиниваленол (ДОН) обнаружен в 15 образцах с максимальным содержанием 420 мкг/кг, а фумонизин $\mathrm{B}_{1}\left(Ф_{1}\right)$ не выявлен. На искусственном инфекционном фоне зараженность зерна составила 25.8 \% (2-54 \%), количество ДНК F. graminearum было значительно выше, чем в естественных условиях, и варьировало в пределах (4.24-49.8) × 10-3 нг/нг. Образцы зерна всех сортов пшеницы, выращенных на искусственном инфекционном фоне F. graminearum, содержали ДОН в высоких количествах - от 20255 до 79245 мкг/кг. Выявлено значительное содержание ФВ в диапазоне от 980 до 20326 мкг/кг. Сорт Адель охарактеризован как высокоустойчивый к заражению грибами и накоплению микотоксинов. К относительно устойчивым отнесены сорта Антонина, Лебедь, Память, а наиболее восприимчивым оказался сорт Утриш. Установлены сходство реакций устойчивости сортов пшеницы к заражению F. graminearum и F. verticillioides и существующие между грибами взаимодействия в процессе колонизации зерна.

Ключевые слова: пшеница; сорта; устойчивость; грибы; Fusarium; ДНК; микотоксины; инфекционный фон; количественная ПЦР. 
I ecological farming, one of the major thrusts is the cultivation of crops that are resistant to various biotic and abiotic stress factors. Obtainment and selection of specific plant forms along with the creation of prospective gene pools is a complicated long-term work of scientific teams, bringing a spectrum of high-productive varieties with different amounts of resistance to particular environmental stress factors (Bespalova et al., 2012, 2017; Ablova et al., 2014). Largescale cultivation essentially helps in the breeding of crop varieties, as they must be both best adapted to the conditions of the site and resistant to some of the most hampful diseases. Thus, potential productivity of that particular variety can be maximized, which helps to increase the gross grain harvest of high-quality wheat.

Fusarium head blight (FHB) of wheat is one of the most destructive diseases in the south of European part of Russia (Gagkaeva et al., 2014). Some widespread species of Fusarium fungi produce various mycotoxins which can cause serious health problems in humans and animals who consume contaminated grains. In Northern Caucasus, including the Krasnodar region, severe epidemics of FHB were recorded for wheat in the years 1988, 1992, 1993, 2014, 2016 and 2017, and moderate FHB epidemic cases were also recorded in the years 1984-1987, 1990, 1991, 1997, 1998, 2001, 2004, 2006 and 2012. Scientific research and practical work aimed at preventing the loss of grain quality due to infection with Fusarium and contamination with mycotoxins are highly sought after.

The F. graminearum Schwabe is the dominant pathogen of wheat grain grown in North Caucasian region. The pathogen produces deoxynivalenol (DON), a major trichothecene mycotoxin that may accumulate in grains at levels considered unsafe for both human and animal consumption. $F$. verticillioides (Sacc.) Nirenberg and $F$. proliferatum (The Matsushima) Nirenberg, representatives of Gibberella fujikuroi species complex, also infect cereals in the South of Russia. The latter fungi are the main fungal species producing fumonisin mycotoxins, especially fumonisin $\mathrm{B}_{1}$ (FB $)$ comprising up to $70-80 \%$ of the total group of those secondary metabolites (Alexander et al., 2009).

Assessment of plants for their resistance to FHB is a complicated process, since visually detected symptoms of infection are not always distinguishable as they depend on the environmental conditions and peculiarities of the plant morphology. Moreover, host resistance to FHB has been classified into five types, each of which is believed to be independent in assessing a genotype: types I-V. Types I and II refers to the resistance of the plants towards fungal penetration and spread of the disease symptoms in the spike, type III refers to the resistance of the grains to the pathogen, type IV refers to the tolerance, and type $\mathrm{V}$ is the ability to mycotoxin accumulation and/or degradation (Mesterhazy, 2002). For the multi-component evaluation of the resistance of wheat to FHB, different techniques have been applied varying by labour input, efficiency and accuracy of the results obtained.

In this study, we aimed to characterize the resistance of naturally and artificially infected winter wheat varieties to FHB. The varieties were evaluated by the disease assessment parameters that describe different types of host resistance: in case of type III resistance, the percentage of Fusarium- damaged grains (FDG) detected by visual and mycological analysis along with the fungal DNA content were used; type IV resistance was evaluated by comparison of the grain yield in inoculated versus non-inoculated plants treated by fungicide and $\mathrm{V}$ type resistance was measured by the quantitative analysis of mycotoxins in the grain.

\section{Materials and methods}

Grain samples. In this study, the following 17 winter wheat varieties, created by the breeders from the National Center of Grain (Krasnodar, Russia), were used: Adel, Alekseich, Antonina, Bagrat, Bezostaya 100, Brigada, Vassa, Velena, GROM, Gurt, Kurs, Lebed, Morozko, Pamyat, Tanya, Utrish and Yuka. These varieties were grown in the Krasnodarsky region in 2016 under the natural and artificial infections according to the standard crop husbandry practices at the National Center of Grain.

Field tests. With respect to natural infection, wheat varieties were grown after growing sunflower as a previous crop at fungicide-free experimental plots measuring $10 \mathrm{~m}^{2}$. In case of artificial infection, the same set of varieties was cultivated on another field after siderating and was artificially inoculated with $F$. graminearum during the flowering period. On the experimental plot where artificial inoculation was performed, the control plants (non-inoculated plants) of each variety with the application of fungicide were undertaken.

When at midanthesis, wheat heads were inoculated with a conidial suspension (total concentration of 3-5 $\times 10^{6}$ spores $/ \mathrm{mL}$ ) at a rate of $100 \mathrm{~mL} / \mathrm{m}^{2}$ using a knapsack sprayer (Ablova, Taranenko, 2004). At harvest, grain from all plots were individually bagged and retained for further analyses.

Plant productivity analysis. The wheat varieties were classified based on their height and according to the classification worked out in the National Center of Grain (Bespalova et al., 2017). The productivity characteristics (total grain weight per the head of the main stem and 1000-grain weight) were evaluated (Babayantz et al., 1988). Post-harvest assessment of grain for FHB on the artificially inoculated plants included determination of percentage Fusariuminfected grains that were visually detected in the sample by distinguishable signs of damage (shriveled, pale and pink coloured).

Mycological assessment of grain infection. To evaluate the latent Fusarium infection and species composition, the grains of each sample were surface sterilized in $5 \%$ sodium hypochlorite and washed by sterilized water. Finally, 100 surface-sterilized grains were placed per Petri plates onto the potato-sucrose agar medium and incubated in the dark at $24{ }^{\circ} \mathrm{C}$. After seven days, the latent fungal infection was registered and Fusarium species were identified (Gerlach, Nirenberg, 1982).

Molecular diagnostic assay. The grain samples (20 g) were homogenized in sterilized grinding chambers of a batch mill Tube Mill Control (IKA). Total DNA from $200 \mathrm{mg}$ of ground grains and DNA of $F$. graminearum and $F$. verticillioides fungal mycelium were extracted with the Genomic DNA Purification Kit (Thermo Fisher Scientific). The DNA content of wheat per total DNA sample was evaluated by quantitative PCR (qPCR) method with SYBR Green dye, while fungal DNA was quantified with qPCR with TaqMan probes. The 
Table 1. Oligonucleotide primers and probes used in this study

\begin{tabular}{|c|c|c|c|}
\hline Target object & Primers and probes & Nucleotide sequences $\left(5^{\prime} \rightarrow 3^{\prime}\right)$ & References \\
\hline \multirow{2}{*}{ Wheat } & Hor $1, f$ & TCTCTGGGTTTGAGGGTGAC & \multirow[t]{2}{*}{ Nicolaisen et al., 2009} \\
\hline & Hor $2, r$ & GGCCCTTGTACCAGTCAAGGT & \\
\hline \multirow[t]{3}{*}{ F. graminearum } & TMFg12,f & CTCCGGATATGTTGCGTCAA & \multirow[t]{3}{*}{ Yli-Mattila et al., 2008} \\
\hline & TMFg12,r & CGAAGCATATCCAGATCATCCA & \\
\hline & TMFg12,p & FAM-TGAGAATGTCTTGAGGCAATGCGAACTTT-BHQ1 & \\
\hline \multirow[t]{3}{*}{ Tri-Fusarium* } & TMTrif & CAGCAGMTRCTCAAGGTAGACCC & \multirow[t]{3}{*}{ Halstensen et al., 2006} \\
\hline & TMTrir & AACTGTAYACRACCATGCCAAC & \\
\hline & TMTrip & Cy5-AGCTTGGTGTTGGGATCTGTCCTTACCG-BHQ2 & \\
\hline \multirow[t]{3}{*}{ Fum-Fusarium* } & fum1_fw & ATGCAAGAGGCGAGGCAA & \multirow[t]{3}{*}{ Preiser et al., 2015} \\
\hline & fum1_rev & GGCTCTCAGAGCTTGGCAT & \\
\hline & fum1_probe & Cy5-CAATGCCATCTTCTTGAAACCT-BHQ2 & \\
\hline
\end{tabular}

* Tri-Fusarium and Fum-Fusarium are trichothecene- or fumonisin-producing Fusarium species, respectively.

amount of DNA of $F$. graminearum, the group of fungal species producing trichothecene mycotoxins (Tri-Fusarium) and of those producing fumonisins (Fum-Fusarium), were determined in every total DNA samples. Table 1 presents the sequences of using primers and probes for qPCR. All qPCR assays were run using the CFX 96 Real-Time System (BioRad) thermocycler. DNA solutions of the Fusarium strains were diluted to $10 \mathrm{ng} / \mu \mathrm{L}$ and used to construct calibration curves in subsequent dilutions of factors of 10 from $10^{-1}$ to $10^{-6} \mathrm{ng} / \mu \mathrm{L}$. Fold-differences and standard error were calculated from $\mathrm{Ct}$ values, which were normalized against the DNA of pure cultures of $F$. graminearum and $F$. verticillioides using BioRad CFX Manager 1.6 software package. DNA content was presented as the ratio of fungal DNA to wheat DNA in each sample (ng/ng).

Analysis of mycotoxins. DON and $\mathrm{FB}_{1}$ were quantified by the enzyme-linked immunosorbent assay (ELISA). Mycotoxins were extracted from $1 \mathrm{~g}$ of ground grain with 5 $\mathrm{mL}$ of acetonitrile:water mixture (volume proportion 84:16) for $14-16 \mathrm{~h}$ by shaking in a horizontal shaker S-3M (ELMI) at $300 \mathrm{rpm}$. Diagnostic test-systems 'Deoxynivalenol-ELISA' and 'Fumonisin-ELISA' (Russia) were used. Detection limits for both mycotoxins were $20 \mu \mathrm{g} / \mathrm{kg}$.

Statistical analysis. All samples were analysed at least twice. Data were analysed by using Microsoft Office Excel 2007 and Statistica 10.0 (ANOVA). Differences were considered significant at $p<0.05$.

\section{Results}

Height of plants and characteristics of productivity. The height of wheat plants varied substantially from 87 to 125 $\mathrm{cm}$; therefore, based on their heights, wheat varieties were subdivided into four groups: tall, medium, short-stemmed and semi-dwarf. The variety Adel was grouped under the tall category (more than $120 \mathrm{~cm}$ ); Bagrat, Brigada, Bezostaya 100, Vassa, Kurs, Lebed, Morozko, Pamyat and Yuka were grouped under medium categories (up to $120 \mathrm{~cm}$ ). The group of shortstemmed varieties (up to $105 \mathrm{~cm}$ ) comprised Antonina, Velena, Gurt and Utrish, whereas the varieties Alekseich, GROM and Tanya were grouped under semi-dwarf varieties.
In the control samples of every variety after the application of fungicide, the 1000-grain weight varied from $35.8 \mathrm{~g}$ (Velena) to $51 \mathrm{~g}$ (Vassa); the grain weight per head varied from $1.6 \mathrm{~g}$ (Morozko) to $2.95 \mathrm{~g}$ (Vassa).

Grain infection with Fusarium fungi. In wheat varieties, grain infection with Fusarium fungi was determined by two methods: conventional mycological method and visual counting of the number of grains with distinguishable signs of the disease (for artificial infection only). Under natural infection, mycological analysis detected the latent Fusarium infection on an average of $6.1 \%$ with the maximum content ( $15 \%$ ) being registered for the variety Utrish (Table 2).

The main representative of fungi in grain was $F$. graminearum; its share of the number of all Fusarium fungi was 34.8 \%. F. sporotrichioides Sherb., F. tricinctum (Corda) Sacc., F. semitectum Berk. \& Ravenel, F. equiseti (Corda) Sacc. and $F$. verticillioides infected the wheat grains more rarely.

In case of artificial infection, the number of distinguishable FDG varied from 13.3 to $63.1 \%$ per sample (average, $33.8 \%$ ) (Table 3 ). According to the data of the mycological analysis, latent infection of grain accounted for 2.0-54.0\% (average, $25.8 \%$ ). In case of both methods, the maximum values of FDG were recorded for the variety Utrish, and the minimum values were recorded for the variety Adel. Varieties Pamyat, Lebed, Antonina and Velena showed low levels of infection.

In the grains of all varieties of wheat, not only $F$. graminearum infection, which was used to inoculate plants, but also the presence of $F$. verticillioides, was recorded. It is noteworthy that the infection by the latter species was on an average about 11.5 times greater than infection by $F$. graminearum. In addition, single cases of $F$. proliferatum occurrence were recorded (grain infection by less than 1-2\%). This shows that the fungus $F$. verticillioides is the main producer of $\mathrm{FB}_{1}$. In case of grain of wheat grown under artificial inoculation, other species of Fusarium fungi were not detected.

Content of fungal DNA in grain. In case of all wheat varieties grown under natural infection, the amount of $F$. graminearum DNA was found to vary within a range of (1.1$42.7) \times 10^{-5} \mathrm{ng} / \mathrm{ng}$. Based on this, the varieties were grouped under three categories: the first one comprised relatively 
Table 2. Characteristics of wheat varieties grown under natural infection of Fusarium fungi

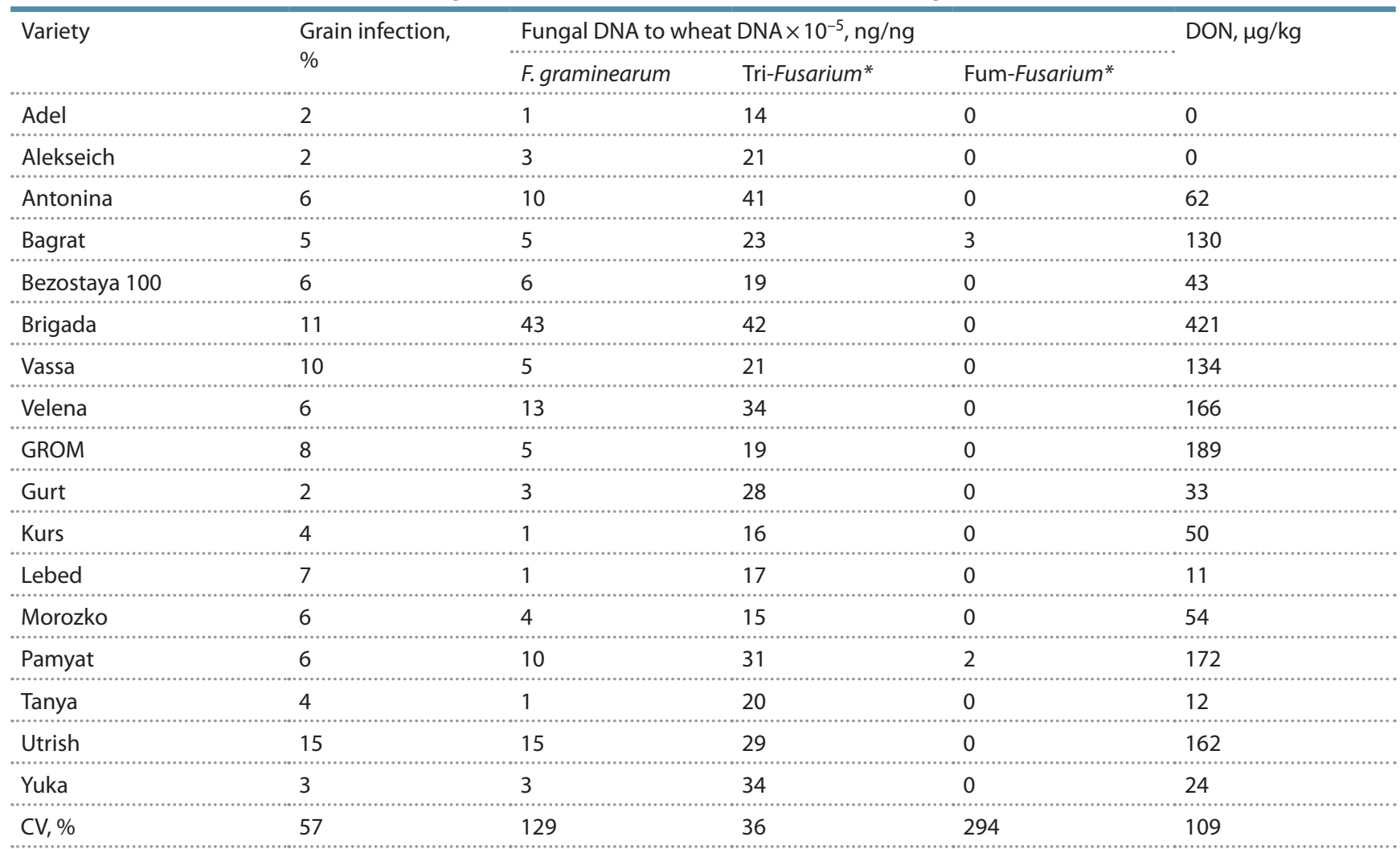

* Tri-Fusarium and Fum-Fusarium are trichothecene- or fumonisin-producing Fusarium species, respectively; CV - coefficient of variation.

Table 3. Characteristics of wheat varieties grown under artificial infection of $F$. graminearum

\begin{tabular}{|c|c|c|c|c|c|c|c|c|}
\hline \multirow[t]{2}{*}{ Variety } & \multirow[t]{2}{*}{$\begin{array}{l}\text { 1000-grain } \\
\text { weight, g }\end{array}$} & \multirow{2}{*}{$\begin{array}{l}\text { Grain weight } \\
\text { per the head, } \\
\mathrm{g}\end{array}$} & \multicolumn{2}{|c|}{$\begin{array}{l}\text { Fusarium-damaged } \\
\text { grain, } \%\end{array}$} & \multicolumn{2}{|c|}{$\begin{array}{l}\text { Fungal DNA to wheat } \\
\text { DNA } \times 10^{-3}, \mathrm{ng} / \mathrm{ng}^{*}\end{array}$} & \multicolumn{2}{|c|}{$\begin{array}{l}\text { Mycotoxin, } \\
\mu \mathrm{g} / \mathrm{kg}\end{array}$} \\
\hline & & & visible & latent & F. graminearum & Fum-Fusarium* & DON & $\mathrm{FB}_{1}$ \\
\hline Adel & 38.0 & 1.9 & 13 & 2 & 7 & 5 & 23069 & 1471 \\
\hline Alekseich & 39.6 & 2.0 & 31 & 42 & 15 & 17 & 35330 & 1800 \\
\hline Antonina & 32.4 & 1.4 & 24 & 14 & 4 & 5 & 29557 & 4435 \\
\hline Bagrat & 30.8 & 1.3 & 52 & 12 & 16 & 9 & 73502 & 5519 \\
\hline Bezostaya 100 & 38.0 & 1.9 & 46 & 27 & 15 & 5 & 46574 & 2172 \\
\hline Brigada & 29.2 & 1.4 & 25 & 33 & 11 & 8 & 20255 & 980 \\
\hline Vassa & 27.6 & 1.2 & 55 & 38 & 21 & 19 & 50655 & 5475 \\
\hline Velena & 38.6 & 2.2 & 24 & 13 & 12 & 7 & 60901 & 3800 \\
\hline GROM & 31.6 & 1.1 & 44 & 44 & 23 & 5 & 51708 & 4360 \\
\hline Gurt & 31.1 & 1.2 & 34 & 20 & 15 & 9 & 53048 & 6358 \\
\hline Kurs & 30.1 & 1.1 & 41 & 22 & 22 & 7 & 44124 & 1693 \\
\hline Lebed & 32.3 & 1.6 & 15 & 13 & 14 & 6 & 46572 & 1725 \\
\hline Morozko & 27.2 & 1.5 & 35 & 13 & 10 & 3 & 66193 & 1525 \\
\hline Pamyat & 32.7 & 1.2 & 13 & 30 & 7 & 7 & 41174 & 2898 \\
\hline Tanya & 31.9 & 1.7 & 25 & 39 & 16 & 9 & 45471 & 4105 \\
\hline Utrish & 38.0 & 1.9 & 63 & 54 & 50 & 45 & 55019 & 20326 \\
\hline Yuka & 27.7 & 1.3 & 33 & 23 & 17 & 9 & 76401 & 9288 \\
\hline$C V, \%$ & 12.7 & 22.1 & 43 & 55 & 62 & 95 & 33 & 101 \\
\hline
\end{tabular}

${ }^{*}$ Fum-Fusarium - fumonisin-producing species; CV - coefficient of variation. 
high-resistant varieties (less than $3 \times 10^{-5} \mathrm{ng} / \mathrm{ng}$ ) such as Adel, Tanya, Lebed, Kurs, Gurt and Yuka than that of other varieties; The second group was composed of medium-resistant varieties (from $3 \times 10^{-5}$ to $6 \times 10^{-5} \mathrm{ng} / \mathrm{ng}$ ) such as Alekseich, Morozko, GROM, Vassa, Bagrat and Bezostaya 100 and the third group included relatively susceptible varieties (more than $6 \times 10^{-5} \mathrm{ng} / \mathrm{ng}$ ) such as Utrish, Antonina, Pamyat, Velena and Brigada. In case of all samples, the Tri-Fusarium DNA was also detected in the range of (13.9-42.3) $\times 10^{-5} \mathrm{ng} / \mathrm{ng}$. On the contrary, the Fum-Fusarium DNA was detected only in two wheat varieties, namely, Pamyat and Bagrat, with average amounts of DNA of $1.9 \times 10^{-5} \mathrm{ng} / \mathrm{ng}$ and $3.3 \times 10^{-5}$ $\mathrm{ng} / \mathrm{ng}$, respectively.

In case of wheat varieties that were artificially inoculated, the grain samples contained significantly more amount of DNA of $F$. graminearum than that of naturally infected wheats; it varied within a range of $(4.24-49.8) \times 10^{-3} \mathrm{ng} / \mathrm{ng}$. Varieties Antonina, Pamyat, Adel and Morozko demonstrated the lowest level of fungal DNA than that of other varieties, whereas the largest amount was recorded for Utrish, Vassa, Kurs and GROM varieties. The grain samples of artificially inoculated plants were found to contain $(3.4-44.8) \times 10^{-3} \mathrm{ng} / \mathrm{ng}$ of Fum-Fusarium DNA. Similar to F. graminearum, the largest amount of Fum-Fusarium DNA was recorded in the grain samples of Utrish, Vassa and Alekseich varieties and the lowest content was recorded for Antonina, GROM, Bezostaya 100 and Morozko varieties.

Content of mycotoxins in grain. In case of natural infection, DON was detected in the grain of 15 wheat varieties, but the other two varieties, namely, Adel and Alekseich did not show its presence. Maximum DON content $(420 \mu \mathrm{g} / \mathrm{kg})$ was detected in the grain of Brigada variety, which also contained the maximum amount of $F$. graminearum DNA. In the wheat grown under natural infection, the samples of grain did not show the presence of mycotoxin $\mathrm{FB}_{1}$.

Under artificial inoculation with $F$. graminearum, all grain samples showed the presence of DON, varying from 20255 to $79245 \mu \mathrm{g} / \mathrm{kg}$. Varieties Yuka and Bagrat showed the maximum levels. $\mathrm{FB}_{1}$ was present in the range of $980-20326 \mu \mathrm{g} / \mathrm{kg}$ in all wheat varieties. The minimum content of $\mathrm{FB}_{1}$ was detected in Brigada variety, whereas the maximum content was detected in Utrish variety. In grain of Bagrat, Vassa, Gurt and Yuka, the $\mathrm{FB}_{1}$ content exceeded the average value for this mycotoxin $(4584 \mu \mathrm{g} / \mathrm{kg})$ as well.

\section{Discussion}

Yield of grains allows us to assess the productivity of wheat varieties and their responses to growing conditions. The productivity of wheat varieties was demonstrated by low coefficients of variation of both the 1000-grain weight $(12.7 \%)$ and the grain weight per head $(22.1 \%)$. This shows that the breeding of varieties was focused on high crop yields and on this basis they were only slightly different.

The coefficient of variation of $F$. graminearum DNA content in grains under natural infection was found to be about $126.3 \%$. At the same time, the Tri-Fusarium DNA content was found to be more levelled; its coefficient of variation being $36.0 \%$. Despite the significant amount of correlation between the amounts of Tri-Fusarium and F. graminearum DNA $(+0.68)$, there is a considerable range in the values of this parameter, which leads us to the following conclusion: wheat genotypes should be compared not by the total DNA content of all trichothecene-producing Fusarium species of different pathogenicity (F. cerealis (Cooke) Sacc., F. culmorum (W. G. Sm.) Sacc., F. langsethiae Torp et Nirenberg, F. poae (Peck) Wollenw., and F. sporotrichioides, etc.), but by the DNA content of the highly aggressive species, that is, F. graminearum.

In the wheat varieties grown under natural infection, a significant association was established between the infection of the grain revealed on the agar medium and the contents of $F$. graminearum DNA $(+0.59)$ and DON $(+0.66)$ and between the latter two characteristics $(+0.90)$ (Table 4).

The ratio of $F$. graminearum DNA to the total content of Tri-Fusarium DNA was found to be more than 1:10 in the relatively resistant varieties, namely, Adel, Tanya, Lebed, Kurs, Gurt and Yuka. They were able to withstand the penetration of less pathogenic species compared to the highly aggressive F. graminearum. On the contrary, in the grains of susceptible varieties, significant amounts of DNA of not only $F$. graminearum, but also of Tri-Fusarium fungi were found with relatively weak expression of pathogenic activity.

In case of natural infection, with respect to the sum of the FDG characteristics (the type III resistance), the following varieties were categorized as relatively resistant: Adel, Lebed, Tanya, Yuka, Gurt and Kurs; the varieties Utrish and Bagrat appeared to be susceptible. Under natural infection, the DON levels found in the grain were low for the possibility of varieties ranking by the $\mathrm{V}$ type of resistance.

However, a substantial correlation between the F. graminearum DNA and DON $(+0.90)$ levels and a lower correlation between the Tri-Fusarium DNA and DON $(+0.55)$ levels confirm that $F$. graminearum plays a major role in grain infection and mycotoxin contamination under natural infection.

In case of artificial inoculation, a significant and positive correlation was recorded between the number of FDG that were visually revealed as well as detected by the mycological analyses $(+0.50)$ (Table 5). In addition, there was a significant and positive correlation between the aforementioned parameters and the contents of the $F$. graminearum and FumFusarium DNA. Nevertheless, only the number of grains with visually detected symptoms showed significant negative correlation with productivity characteristics, namely, the grain weight per head and the 1000-grain weight.

Values of the presence of $F$. graminearum DNA and its metabolite DON in the grain were levelled, the coefficients of variation being 62 and $33 \%$, respectively. Grain infection by $F$. verticillioides and $\mathrm{FB}_{1}$ contamination values was much more considerable; the respective coefficients of variation were found to be about 95 and $101 \%$. The total numbers of FDG (visually damaged and latent) was positive correlated only with the percentage of $F$. verticillioides infection and the latter was correlated with the DNA contents of both FumFusarium and F. graminearum.

Artificially inoculated varieties - Adel, Pamyat, Morozko and Antonina - appeared to be relatively high-resistant than that of naturally infected varieties, whereas Utrish, Vassa, GROM and Alekseich were found to susceptible to Fusarium fungal infection. The lowest amounts of DON and FB, were found in the varieties Adel, Brigada and Antonina. The variety 
Table 4. Correlation coefficients between measured parameters characterizing wheat varieties under natural infection of Fusarium fungi

\begin{tabular}{|c|c|c|c|c|}
\hline \multirow[t]{2}{*}{ Parameters } & \multirow{2}{*}{$\begin{array}{l}\text { Fusarium-damaged } \\
\text { grain }\end{array}$} & \multicolumn{3}{|l|}{ Fungal DNA } \\
\hline & & F. graminearum & Tri-Fusarium & Fum-Fusarium \\
\hline F.graminearum DNA & $+0.59^{*}$ & & & \\
\hline Tri-Fusarium DNA & +0.27 & $+0.68^{*}$ & & \\
\hline Fum-Fusarium DNA & -0.07 & -0.02 & +0.02 & \\
\hline DON & $+0.66^{*}$ & $+0.90^{*}$ & $+0.55^{*}$ & +0.16 \\
\hline
\end{tabular}

* Significant at $p<0.05$.

Table 5. Correlation coefficients between measured parameters characterizing wheat varieties under artificial infection of F. graminearum

\begin{tabular}{|c|c|c|c|c|c|c|c|c|c|c|}
\hline \multirow[t]{2}{*}{ Parameters } & \multirow[t]{2}{*}{$\begin{array}{l}\text { Height of } \\
\text { plants }\end{array}$} & \multirow[t]{2}{*}{$\begin{array}{l}\text { 1000-grain } \\
\text { weight }\end{array}$} & \multirow{2}{*}{$\begin{array}{l}\text { Grain } \\
\text { weight } \\
\text { per the } \\
\text { head }\end{array}$} & \multicolumn{2}{|c|}{$\begin{array}{l}\text { Fusarium- } \\
\text { damaged grain }\end{array}$} & \multicolumn{2}{|c|}{ Grain infection } & \multicolumn{2}{|c|}{ Fungal DNA } & \multirow[t]{2}{*}{ DON } \\
\hline & & & & visual & latent & $\begin{array}{l}\text { F. grami- } \\
\text { nearum }\end{array}$ & $\begin{array}{l}\text { F. verticilli- } \\
\text { oides }\end{array}$ & $\begin{array}{l}\text { F. grami- } \\
\text { nearum }\end{array}$ & $\begin{array}{l}\text { Fum- } \\
\text { Fusarium }\end{array}$ & \\
\hline 1000-grain weight & +0.20 & & & & & & & & & \\
\hline $\begin{array}{l}\text { Grain weight per the } \\
\text { head }\end{array}$ & +0.18 & $+0.82^{*}$ & & & & & & & & \\
\hline \multicolumn{11}{|l|}{$\begin{array}{l}\text { Fusarium-damaged } \\
\text { grain }\end{array}$} \\
\hline visual & -0.28 & $-0.54^{*}$ & $-0.64^{*}$ & & & & & & & \\
\hline latent & $-0.58^{*}$ & -0.08 & -0.39 & $+0.50^{*}$ & & & & & & \\
\hline $\begin{array}{l}\text { Grain infection by } \\
\text { F. graminearum }\end{array}$ & -0.30 & -0.10 & -0.30 & +0.12 & +0.27 & & & & & \\
\hline $\begin{array}{l}\text { Grain infection by } \\
\text { F. verticillioides }\end{array}$ & $-0.51^{*}$ & -0.19 & -0.27 & $+0.54^{*}$ & $+0.63^{*}$ & +0.23 & & & & \\
\hline DNA of F. graminearum & -0.26 & -0.23 & -0.41 & $+0.75^{*}$ & $+0.66^{*}$ & +0.09 & $+0.56^{*}$ & & & \\
\hline DNA of Fum-Fusarium* & -0.25 & -0.13 & -0.30 & $+0.60^{*}$ & $+0.65^{*}$ & -0.25 & $+0.52^{*}$ & $+0.87^{*}$ & & \\
\hline DON & -0.32 & -0.41 & -0.15 & +0.47 & -0.05 & +0.08 & +0.48 & +0.30 & +0.11 & \\
\hline $\mathrm{FB}_{1}$ & -0.31 & $-0,14$ & -0.23 & $+0.59^{*}$ & +0.48 & -0.08 & $+0.63^{*}$ & $+0.83^{*}$ & $+0.85^{*}$ & +0.39 \\
\hline
\end{tabular}

* Significant at $p<0.05$.

Alekseich appeared to accumulate more DON in its grains, whereas the varieties Tanya and Alekseich accumulated more $\mathrm{FB}_{1}$.

Our study showed some contradictory results with respect to the types of resistance of some varieties. For example, the variety Brigada exhibited a resistance to FDG and accumulation of DON under artificial inoculation, despite its high susceptibility as shown under natural infection. The variety Alekseich was characterized as relatively resistant based on the fungal DNA content and the amount of mycotoxins, although it demonstrates high fungal infection. In case of variety Vassa, no infection with $F$. graminearum was revealed by the mycological analysis, but the $F$. graminearum DNA and DON contents were detected in mean values, whereas the Fum-Fusarium and $\mathrm{FB}_{1}$ contents were found to be high. These differences may be attributed to the interactions of fungi and/or environmental conditions.

We did not expect a considerable infection of grains with $F$. verticillioides in case of artificially inoculated plants with F. graminearum at midanthesis. Probably, the residues of maize plants from the neighbouring field may have provided the source of infection. $F$. verticillioides is the most commonly reported fungal species infecting maize and is able to remain long on the crop residues even after harvesting (Dill-Macky, Jones, 2000; Maiorano et al., 2008). The reported measures revealed significant negative correlation between the height of wheat varieties and the $F$. verticillioides infection of the grains $(-0.51)$, which proves the role of plant residues on the soil surface as a source of infection. However, there was no association between the plant height and the $F$. graminearum infection mainly resulting from spraying of wheat varieties by the suspension of conidia.

On an average, the $F$. verticillioides infection was more than 10 times as high as the F. graminearum one (Figure). Nonetheless, for $F$. verticillioides, the infection correlated with the number of visually FDG $(+0.54)$ and latent Fusarium infection of grain $(+0.63)$, but no correlation was detected with $F$. graminearum. $F$. verticillioides infection was also significantly associated with the amounts of both $\mathrm{FB}_{1}(+0.63)$ and DNA of the analysed fungi $(+0.52$ and +0.56$)$. On an 
average, the $F$. graminearum DNA content was comparable to the Fum-Fusarium, although the amount of DON greatly exceeded the amount of $\mathrm{FB}_{1}$.

The results demonstrate that in case of high fungal infection, the percentage of grain infection with $F$. graminearum was not associated with as DNA content of this pathogen, nor with the amount of DON. In this case unexpectedly the significant positive correlations between the $F$. graminearum DNA and Fum-Fusarium DNA $(+0.83)$ and also FB $(+0.87)$ were detected. Probably, F. graminearum contributes to the plant colonization by $F$. verticillioides and its production of the mycotoxin. DON is known to be the aggressiveness factor of F. graminearum, which promotes the spread of the pathogen over the plant tissue (Alexander et al., 2009; Audenaert et al., 2013). On the contrary, fumonisins are not so important for $F$. verticillioides infection of maize, as no dependence was found between the aggressiveness of fungal isolates and their ability to the production of fumonisins (Desjardins, Plattner, 2000; Desjardins et al., 2002; Presello et al., 2006; Iglesias et al., 2010). In co-inoculation of maize with F. graminearum and $F$. verticillioides, French researchers showed that $F$. verticillioides has competitive advantages over the $F$. graminearum strains and that previous inoculation with $F$. graminearum in maize ears can facilitate subsequent infections by $F$. verticillioides (Picot et al., 2012).

Occurrence of the fungi within a grain sample or even a single grain inevitably leads to their interactions, which influences the production of secondary metabolites. Usually, fumonisins are revealed in maize grain. However, increasing areas of maize cultivation are bound to bring about the increase in importance of fumonisins upon other cultures, including small grain cereals. In spite of growing occurrence of $F$. verticillioides, $F$. proliferatum and their mycotoxins in wheat and barley grain, information regarding the interactions of those fungi and plant species is still unknown (Stanković et al., 2011). Thus, concurrent presence of both trichothecene and fumonisins mycotoxins seriously deteriorates the edibility and forage quality of the grain harvest.

It is essential to enhance breeding of high-resistant cereals to Fusarium infection, which do not accumulate mycotoxins in their grains. Cultivation of resistant cultivars is still one of the most efficient methods of plant protection, thus providing abundant high-quality harvest.

\section{Conclusion}

From all the studied winter wheats, the variety Adel was found as highly resistant to $F$. graminearum and $F$. verticillioides infection and also to contamination by the mycotoxins $\mathrm{DON}$ and $\mathrm{FB}_{1}$. On the base of sum of measured parameters, varieties Antonina, Lebed and Pamyat can be characterized as relatively resistant, whereas the variety Utrish as the most susceptible to FHB. We observed a similarity in the response of wheat varieties to both $F$. graminearum and $F$. verticillioides infections, and the obvious interaction of the fungi in the process of grain colonization. It is essential to enhance the breeding of high-resistant to FHB wheat varieties and increase their widespread cultivation.
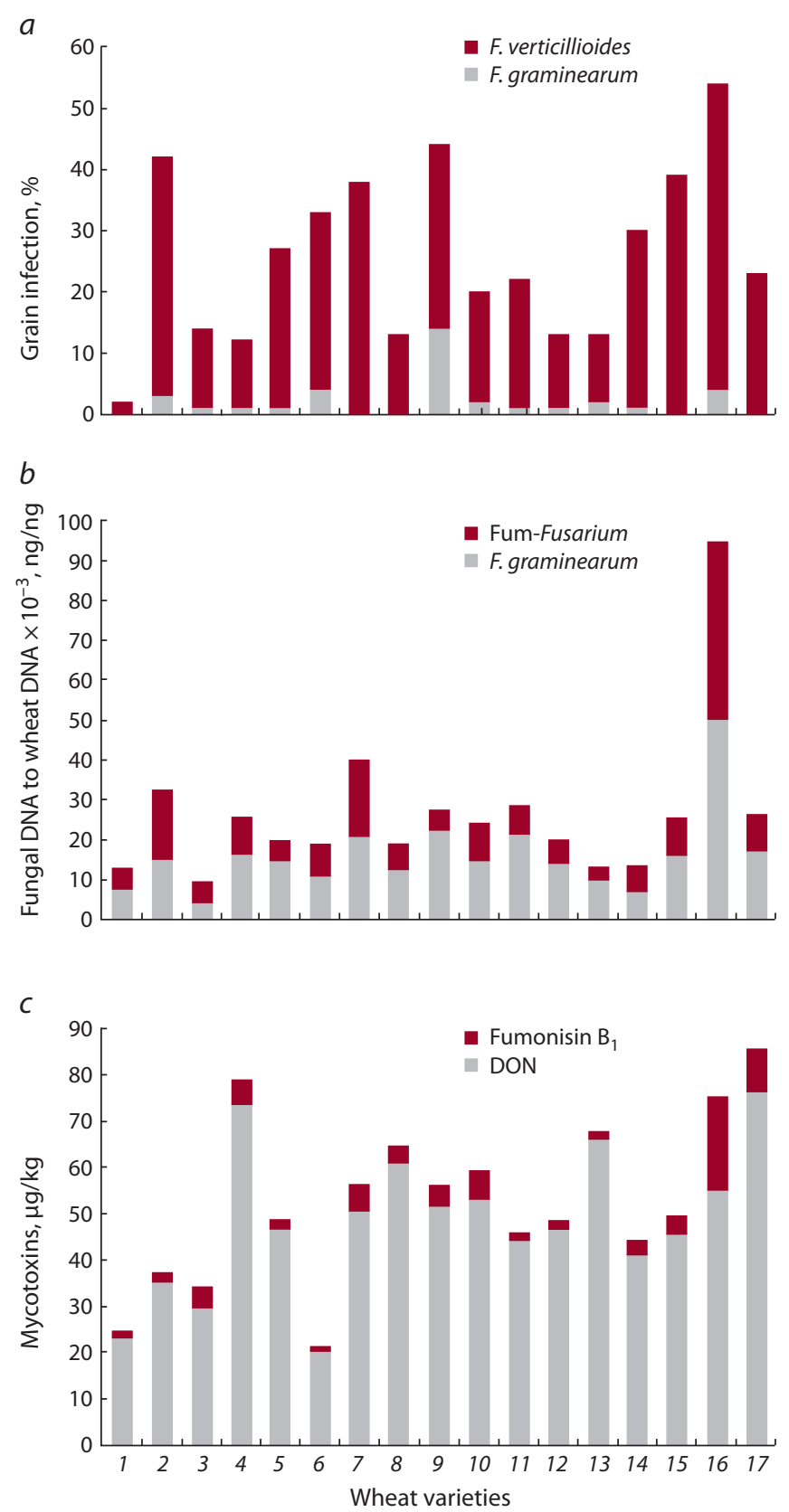

Comparison of parameters characterizing the resistance of winter wheat varieties under the artificial infection: (a) percentage of grains infected by F. graminearum and $F$. verticillioides, (b) DNA content of these fungi and (c) content of produced mycotoxins.

The variety: 1 - Adel; 2 - Alekseich; 3 - Antonina; 4 - Bagrat; 5 - Bezostaya 100; 6 - Brigada; 7 - Vassa; 8 - Velena; 9 - GROM; 10 - Gurt; 11 - Kurs; 12 - Lebed; 13 - Morozko; 14 - Pamyat; 15 - Tanya; 16 - Utrish; 17 - Yuka.

\section{Acknowledgements}

This study was supported by Russian Science Foundation (project No. 14-26-00067).

\section{Conflict of interest}

The authors declare no conflict of interest. 


\section{References}

Ablova I.B., Bespalova L.A., Kolesnikov F.A., Nabokov G.D., Puzyurnaya O.Yu., Filobok V.A. Wheat breeding for disease resistance. Zemledelie $=$ Agriculture. 2014;3:19-22. (in Russian)

Ablova I.B., Taranenko S.A. Methodological aspects of the creation of artificial infection background for Fusarium head blight of winter wheat. Evolution of Scientific Technologies in Plant Science. 2004;1:382-390. (in Russian)

Alexander N.J., Proctor R.H., McCormick S.P. Genes, gene clusters, and biosynthesis of trichothecenes and fumonisins in Fusarium. Toxin Rev. 2009;28(2-3):198-215. DOI 10.1080/15569540903092142.

Audenaert K., Vanheule A., Höfte M., Haesaert G. Deoxynivalenol: a major player in the multifaceted response of Fusarium to its environment. Toxins. 2013;6:1-19. DOI 10.3390/toxins6010001.

Babayants L.T., Meshterkhazi A., Vekhter V. Methods of Breeding and Assessment of Disease Resistance of Wheat and Barley in CMEA Countries. Prague, 1988. (in Russian)

Bespalova L.A., Romanenko A.A., Kolesnikov F.A., ..., Kalmysh A.P., Ponomarev D.A., Belyakova A.Yu. Varieties of Wheat and Triticale from the Lukyanenko Agricultural Research Institute. Krasnodar, 2017. (in Russian)

Bespalova L.A., Vasilyev A.V., Ablova I.B., Filobok V.A., Khudokormova Z.N., Davoyan R.O., Davoyan E.R., Karlov G.I., Soloviev A.A., Divashuk M.G., Mayer N.K., Dudnikov M.V., Mironenko N.V., Baranova O.A. The use of molecular markers in wheat breeding at the Lukyanenko Agricultural Research Institute. Russian Journal of Genetics: Applied Research. 2012;2(4):286-290.]

Desjardins A.E., Munkvold G.P., Plattner R.D., Proctor R.H. FUM1 - a gene required for fumonisin biosynthesis but not for maize ear rot and ear infection by Gibberella moniliformis in field tests. Mol. Plant-Microbe Interact. 2002;11:1157-1164. DOI 10.1094/MPMI. 2002.15.11.1157.

Desjardins A.E., Plattner R.D. Fumonisin B (1)-nonproducing strains of Fusarium verticillioides cause maize (Zea mays) ear infection and ear rot. J. Agric. Food Chem. 2000;48:5773-5780.

Dill-Macky R., Jones R.K. The effect of previous crop residues and tillage on Fusarium head blight of wheat. Plant Dis. 2000;84:71-76. DOI 10.1094/PDIS.2000.84.1.71.

Gagkaeva T.Yu., Gavrilova O.P. Grain infection by Fusarium fungi in the Krasnodar and Stavropol regions. Zashchita i Karantin Rasteniy $=$ Plant Protection and Quarantine. 2014;3:30-33. (in Russian)
Gerlach W., Nirenberg H. The Genus Fusarium - a Pictorial Atlas Mitt. Biol. Bund. Ld. Berlin, 1982.

Halstensen A.S., Nordby K.C., Eduard W., Klemsdal S.S. Real-time PCR detection of toxigenic Fusarium in airborne and settled grain dust and associations with trichothecene mycotoxins. J. Environ. Monit. 2006;8:1235-1241. DOI 10.1039/b609840a.

Iglesias J., Presello D.A., Botta G., Lori G.A., Fauguel C.M. Aggressiveness of Fusarium section Liseola isolates causing maize ear rot in Argentina. Eur. J. Plant Pathol. 2010;92(1):205-211. DOI 10.4454/jpp.v92i1.31.

Maiorano A., Blandino M., Reyneri A., Vanara F. Effects of maize residues on the Fusarium spp. infection and deoxynivalenol (DON) contamination of wheat grain. Crop Prot. 2008;27:182-188. DOI 10.1016/j.cropro.2007.05.004.

Mesterhazy A. Theory and practice of the breeding for Fusarium head blight in wheat. J. Appl. Genet. 2002;43A:289-302.

Nicolaisen M., Suproniene S., Nielsen L.K., Lazzaro I., Spliid N.H., Justesen A.F. Real-time PCR for quantification of eleven individual Fusarium species in cereals. J. Microbiol. Methods. 2009;76:234240. DOI 10.1016/j.mimet.2008.10.016.

Picot A., Hourcade-Marcolla D., Barreau C., Pinson-Gadais L., Caron D., Richard-Forget F., Lannou C. Interactions between Fusarium verticillioides and Fusarium graminearum in maize ears and consequences for fungal development and mycotoxin accumulation. Plant Pathol. 2012;61:140-151. DOI 10.1111/j.1365-3059.2011.02503.x.

Preiser V., Goetsch D., Sulyok M., Krska R., Mach R.L., Farnleitner A., Brunner K. The development of a multiplex real-time PCR to quantify Fusarium DNA of trichothecene and fumonisin producing strains in maize. Anal. Methods. 2015;7:1358-1365.

Presello D.A., Iglesias J., Botta G., Lori G.A., Eyherabide G.H. Stability of maize resistance to the ear rots caused by Fusarium graminearum and $F$. verticillioides in Argentinean and Canadian environments. Euphytica. 2006;147:403-407. DOI 10.1007/s10681-005-9037-8.

Stanković S., Lević J., Krnjaja V. Fumonisin $\mathrm{B}_{1}$ in maize, wheat and barley grain in Serbia. Biotechnol. Animal Husb. 2011;27(3):631641. DOI 10.2298/BAH1103631S.

Yli-Mattila T., Paavanen-Huhtala S., Jestoi M., Parikka P., Hietaniemi V., Gagkaeva T., Sarlin T., Haikara A., Laaksonen S., Rizzo A. Real-time PCR detection and quantification of Fusarium poae, $F$. graminearum, $F$. sporotrichioides and $F$. langsethiae in cereal grains in Finland and Russia. Arch. Phytopathol. Plant Protect. 2008; 41:243-260. DOI 10.1080/03235400600680659.

\section{ORCID ID}

T.Yu. Gagkaeva orcid.org/0000-0002-3276-561X

A.S. Orina orcid.org/0000-0002-7657-6618
O. Gavrilova orcid.org/0000-0002-5350-3221

I.B. Ablova orcid.org/0000-0002-3454-9988

L.A. Bespalova orcid.org/0000-0003-3844-9682 